\title{
NS

\section{TOBACCO CONTROL IN AUSTRALIA: VICTIMS OF OUR PAST SUCCESS?}

\section{Simon Chapman}

School of Public Health

University of Sydney

\section{GUEST EDITORIAL}

Australia has arguably the lowest smoking prevalence attributable to tobacco control of any nation (Table 1). ${ }^{1}$ Two Asian nations (Singapore and the Chinese territory of Hong Kong) have lower overall smoking prevalence, when the rates for both men and women are combined, but this reflects deeplyembedded cultural proscriptions against smoking by women (for example, only 3.5 per cent of Singaporean women smoke) in addition to the success of tobacco control measures there. Swedish men (17.4 per cent) smoke less than Australian men (21.1 per cent) but this is because of the prevalence of the use of snus (chewing tobacco) among Swedish males. ${ }^{2}$

\section{TABLE 1}

SMOKING PREVALENCE IN SELECTED COUNTRIES AND TERRITORIES, 2003

\begin{tabular}{|lcccccc|}
\hline $\begin{array}{l}\text { Country } \\
\text { or } \\
\text { Territory }\end{array}$ & $\begin{array}{c}\text { Adult } \\
\text { men } \\
\%\end{array}$ & $\begin{array}{c}\text { Adult } \\
\text { women } \\
\%\end{array}$ & $\begin{array}{c}\text { Overall } \\
\text { adult } \\
\%\end{array}$ & $\begin{array}{c}\text { Male } \\
\text { youth } \\
\%\end{array}$ & $\begin{array}{c}\text { Female } \\
\text { youth } \\
\%\end{array}$ & $\begin{array}{c}\text { Overall } \\
\text { youth } \\
\%\end{array}$ \\
\hline Australia & 21.1 & 18.0 & 19.6 & 14.1 & 16.2 & 15.2 \\
Canada & 23.9 & 19.6 & 21.8 & 16.2 & 20.9 & 18.6 \\
USA & 25.7 & 21.0 & 23.4 & 26.0 & 20.1 & 23.1 \\
UK & 28.0 & 26.0 & 27.0 & 24.0 & 28.0 & 26.0 \\
Sweden & 17.4 & 20.4 & 18.9 & 26.0 & 25.0 & 25.5 \\
Norway & 31.0 & 32.0 & 31.5 & 31.0 & 34.0 & 32.5 \\
New Zealand & 25.1 & 24.8 & 25.0 & 16.3 & 22.0 & 19.2 \\
Singapore & 24.2 & 3.5 & 13.9 & 13.4 & 8.8 & 11.1 \\
Hong Kong & 25.2 & 4.4 & 14.8 & 17.0 & 13.0 & 15.0 \\
Malaysia & 49.2 & 3.5 & 26.4 & 25.1 & 0.6 & 12.9 \\
\hline
\end{tabular}

Source: Shafey O, Dolwick S, Guindon GE. Tobacco Control Country Profiles 2003.

Our track record in tobacco control is second to none. Tobacco industry documents repeatedly acknowledge this with statements like: 'Australia has one of the best organised, best financed, most politically savvy and well connected antismoking movements in the world. They are aggressive and

continued on page 86

\section{CONTENTS}

85 Tobacco control in Australia: Victims of our past success?

87 Current tobacco smoking by the NSW population and the consequences for health

92 The social costs of smoking in Australia

95 A report on the NSW Tobacco Action Plan 2001-2004

98 Managing nicotine dependence in NSW hospital patients

102 Litigation and its current role in tobacco regulation in Australia

104 Promoting tobacco to the young in the age of advertising bans

108 The impact of low-tar cigarettes

111 Tobacco and Health FactSheet : Light cigarettes

112 Continuous NSW Health Survey: Quarterly report on health status, health behaviours, and risk factors

114 Contesting freedoms in healthcare: The 10th conference of the Australasian Bioethics Association, November 2004

115 Communicable Diseases Report, NSW, for March and April 2004

115 Trends

115 Two clusters of measles linked to overseas travel

115 Two clusters of Legionnaires' disease

117 Pertussis in a nursery

117 Salmonella Typhimurium outbreak in NSW

117 Viral gastroenteritis at a sport camp

117 Severe Acute Respiratory Syndrome

118 HIV notifications in NSW in 2003 
have been able to use the levers of power very effectively to propose and pass draconian legislation ...The implications of Australian anti-smoking activity are significant outside Australia because Australia serves as a seedbed for anti-smoking programs around the world. ${ }^{3}$

Currently, we do not have the world's strongest health warnings on cigarette packs but we will join Brazil, Canada, Singapore, and Thailand in introducing uncompromising pictorial pack warnings in the next two years. ${ }^{4}$ Our retail prices, adjusted for purchasing power, are the third highest in the world behind Hong Kong and New Zealand. ${ }^{5}$ The local tobacco industry acknowledges that Australia and Canada have the 'darkest' markets in the world in terms of advertising and marketing restrictions. ${ }^{6}$ In contrast to its former high profile campaigning ability in every advertising medium, the local industry has been reduced to promoting whispering campaigns about the virtues of its products. ${ }^{7}$

In restricting smoking and providing smoke-free public spaces, Australia lags behind several countries and states such as Ireland, California, and New York, which have banned smoking throughout the hospitality industry. However, Australia would certainly be listed in any 'Top Five' list of countries where the people's right to breathe air unpolluted by tobacco smoke is protected. Our public awareness campaigns, such as Every Cigarette Is Doing You Damage ${ }^{8}$ have been exported to many nations, and we have a global reputation for advocacy. ${ }^{9}$

The above summary suggests that, by world standards, Australia is doing well in tobacco control. Yet to speak of this as a success story requires us to ask whether one in five Australians continuing to smoke every day, ${ }^{10}$ and over 19,000 deaths each year attributable to tobacco use, ${ }^{10}$ can be termed a successful outcome. Nineteen-thousand deaths is higher than all combined annual deaths from breast, skin, and cervical cancers, road deaths, suicide, AIDS, alcohol , and illicit drugs. ${ }^{10}$

Tobacco control in Australia has reached an important crossroad. Many of the traditional platforms of comprehensive tobacco control have been implemented, and today there are concerning signs that governments have lost sight of the importance of tobacco control. Official statements such as 'Tobacco smoking is the single largest preventable cause of premature death and disease in Australia' are cited in policy documents, ${ }^{11}$ but are supported by program budgets that are small compared to those allocated to programs such as drug and alcohol, suicide, breast cancer, and road injury prevention. ${ }^{12}$ For example, in the federal budget for 2004 just $\$ 2.2$ million was allocated to tobacco control, although the health portfolio budget statement did not separately identify the amount allocated to tobacco. In 2001, investment by federal and state governments in tobacco control totalled $\$ 25$ million. By contrast, the estimated excise tax from tobacco that will be collected in 2005 by the federal government is $\$ 5.2$ billion.
Prime Minister John Howard said on Adelaide radio on 22 July 1999: 'But the only way you could further reduce smoking in this country is probably by making it illegal.' ${ }^{13}$ This statement is not supported by the evidence. For example, the records of California and Massachusetts, which at different stages in the 1990s had well-funded comprehensive tobacco control programs, show that suitably-funded programs can reduce tobacco consumption. In California, after the commencement of a well-funded campaign in 1993, per capita cigarette consumption declined 52 per cent faster than previously (from 9.7 packs per person per month at the beginning of the program to 6.5 packs per person per month), and the decline in tobacco consumption has been significantly greater in California than in the rest of the United States $(P<.001) .{ }^{14}$ In Massachusetts, from 1992 tobacco consumption has shown a consistent decline of more than four per cent per annum, whereas in comparison states consumption has levelled off, decreasing by less than one per cent a year. The prevalence of adult smoking in Massachusetts has declined annually by 0.43 per cent (95\% CI; 0.21-0.66 per cent) compared with an increase of 0.03 per cent (-0.06-0.12 per cent) in comparison states $(P<0.001) .{ }^{15}$

Australia's non-government agencies have proposed that \$96 million spent in 2004-05, including a \$44 million public awareness campaign, could significantly boost the continuing fall in tobacco use in the community. ${ }^{10} \mathrm{An}$ additional tax impost of one cent on a pack of cigarettes would raise an additional $\$ 240$ million each year, which is more than enough to fund a tobacco awareness campaign. Lobbying campaigns have been conducted to promote this 'blue chip' investment in disease prevention for the last few years without success.

So why is tobacco control so unfashionable with governments? Several factors appear to coalesce, in explaining the gap between the acknowledgement that tobacco control should be a health priority and government inaction. First, the erroneous impression that tobacco control has been 'done' is hard to shift in the eyes of some. Second, tobacco use causes chronic disease rather than acute and unexpected episodes of illness. The common attitude that smokers 'have themselves to blame' means that the 'rule of rescue' is not easily invoked as a political imperative for governments to act decisively in tobacco control as it is in other disease conditions. ${ }^{16}$ Consequently, delays in addressing chronic diseases such as those caused by smoking are unlikely to cause outrage among the public.

Visionary policy advocates within government, who are prepared to champion the importance of investment in chronic disease control, are vital in securing the resources required to match the rhetoric of concern with suitablyfunded programs that can 'make smoking history'. This issue of the NSW Public Health Bulletin presents a series of articles relevant to tobacco control in New South Wales. 


\section{REFERENCES}

1. Shafey O, Dolwick S, Guindon GE. Tobacco Control Country Profiles 2003. Available online at www.globalink.org/tccp.

2. Foulds J, Ramstrom L, Burke M, Fagerström K. Effect of smokeless tobacco (snus) on smoking and public health in Sweden. Tobacco Control 2003; 12: 349-359.

3. Philip Morris (Australia) Limited. Corporate Affairs Plan 1992. Available online at http://legacy.library.ucsf.edu/tid/ fgw48e00.

4. Consumer Safety Unit. Regulation impact statement (revised). Trade Practices (Consumer Product Information Standard) (Tobacco) Regulation. Trade Practices Act 1974. Canberra: Commonwealth Department of the Treasury, May 2004.

5. Guindon GE, Tobin S, Yach D. Trends and affordability of cigarette prices: Ample room for tax increases and related health gains. Tobacco Control 2002; 11: 35-43.

6. Chapman S, Byrne F, Carter SM. 'Australia is one of the darkest markets in the world': The global importance of Australian tobacco control. Tobacco Control 2003; 12(S-3): iii1-iii3.

7. Carter SM. Going below the line: Creating transportable brands for Australia's dark market. Tobacco Control 2003; 12 (S-3): iii87-iii94.
8. Hill D, Chapman S, Donovan R. The return of scare tactics. Tobacco Control 1998; 7: 5-8.

9. Chapman S, Wakefield M. Tobacco control advocacy in Australia: Reflections on 30 years of progress. Health Education and Behaviour 2001; 29: 274-289.

10. Scollo M. Tobacco Control: A Blue Chip Investment in Public Health. March 2003. Available online at www.vctc.org.au.

11. Ministerial Council on Drug Strategy. National Tobacco Strategy 1999 to 2002-03. A Framework for Action. Canberra: Commonwealth of Australia, 1999.

12. Chapman S. Tough on drugs, weak on tobacco. Med J Aust 2000;172: 612-14.

13. Transcript of the Prime Minister John Howard. Radio interview with Jeremy Cordeaux (Radio Station 5DN), 22 July 1999.

14. Pierce JP, Gilpin EA, Emery SL, White MM, Rosbrook B, Berry CC, Farkas AJ. Has the California tobacco control program reduced smoking? JAMA 1998; 280: 893-99.

15. Biener L, Harris JE, Hamilton W. Impact of the Massachusetts tobacco control programme: Population based trend analysis. BMJ 2000; 321: 351-54.

16. McKie J, Richardson J. The rule of rescue. Soc Sci Med 2003; 56: 2407-19. F

\section{CURRENT TOBACCO SMOKING BY THE NSW POPULATION AND THE CONSEQUENCES FOR HEALTH}

\author{
Elayne Mitchell and John Sanders \\ Tobacco and Health Branch \\ NSW Department of Health
}

\section{BACKGROUND}

The risk factor responsible for the greatest disease burden in Australia is tobacco smoking, which accounts for approximately 12 per cent of the total burden of disease in males and seven per cent in females. ${ }^{1}$ Tobacco smoking contributes to higher drug-related morbidity and mortality than both alcohol and illicit drug use combined. ${ }^{2}$ It is the leading preventable cause of morbidity and mortality, particularly from: cardiovascular disease; cancers of the lung, larynx and mouth; and chronic obstructive pulmonary disease. It is estimated that approximately half of all long-term smokers will die from smoking-related causes. ${ }^{3}$ Smoking while pregnant contributes to an increased risk of having a low birthweight baby. Exposure to environmental tobacco smoke is known to be a risk factor for lung cancer and cardiovascular disease in adults, and for sudden infant death syndrome, asthma, and lower respiratory disease in children. ${ }^{4}$

This article presents recent Australian and NSW data that describe current tobacco use by the NSW population and provides a context for the other articles in this issue of the NSW Public Health Bulletin that focus on tobacco control in New South Wales.

\section{CURRENT SMOKING PREVALENCE}

Reported prevalence rates for smoking vary according to a variety of factors associated with the design of surveys, including the data collection method used, questions asked, sample size, and the age of the sample population. A recent study discussed the causes of these perceived discrepancies in the prevalence of smoking between two Australian national surveys: ${ }^{5}$ the National Health Survey identifies 'current smokers', including 'daily' plus 'other' and reported a prevalence of 24.3 per cent. 5 The National Drug Strategy Household Survey identifies 'daily', 'weekly', and 'less than weekly', and reported the prevalence of daily smoking to be 19.5 per cent. ${ }^{5}$ After standardising methods and ages, Siahpush reported that the best estimate of smoking prevalence to be almost identical in both surveys at 24.3 per cent and 24.2 per cent respectively. ${ }^{5}$

Smoking prevalence in Australia is among the lowest of all countries participating in the Organization for Economic Cooperation and Development. ${ }^{6}$ The 2001 National Drug Strategy Household Survey compared smoking prevalence among people aged over 14 years between all Australian states and territories, ${ }^{2}$ and found that NSW had the lowest prevalence of smoking in Australia, with 18.1 per cent of the population smoking daily, and a further 3.4 per cent smoking weekly or less often, giving a total of 21.5 per cent who smoked. Overall, 